\title{
Interaction between planting spacing and wood properties of Eucalyptus clones grown in short rotation
}

\author{
Alice Soares Brito (1), \\ Graziela Baptista Vidaurre ${ }^{(1)}$, \\ José Tarcísio da Silva Oliveira ${ }^{(1)}$, \\ João Gabriel Missia da Silva ${ }^{(1)}$, \\ Ramon Ferreira Oliveira ${ }^{(1)}$, \\ Ananias Francisco Dias Júnior ${ }^{(1)}$, \\ Marina Donária Chaves Arantes (2), \\ Jordão Cabral Moulin ${ }^{(1)}$, \\ Marina Valin ${ }^{(3)}$, \\ Leandro De Siqueira ${ }^{(3)}$, \\ Edival Angelo Valverde Zauza ${ }^{(3)}$
}

\begin{abstract}
Wood quality results from the interaction between the genotype of trees and the silvicultural conditions to which they were subjected. Based on this interaction, research on the factors that add value to the woody raw material has an impact on the production of various forest products. This study aimed to evaluate the influence of different planting spacings $(3 \times 1,3 \times 2,3 \times 3$ and $3 \times 4$ $\mathrm{m}$ ) on the wood properties of three 4-year-old Eucalyptus clones. The wood of each clone was evaluated based on basic density, dry mass, anatomy, structural chemical composition, ash content and higher heating value. For at least one of the three clones studied, the planting spacing explained the variations in the basic density, dry mass, diameter and frequency of vessels and wall thickness of the wood fibers. Regardless of the eucalyptus clone, the area of vessels, the length and fraction of the fiber wall, as well as the contents of extractives, lignin, ash and the higher heating value of the wood were not influenced by the planting spacing. In summary, the change in the useful area alters the properties of wood in eucalyptus genetic materials in different ways and intensities at 4 years old.
\end{abstract}

Keywords: Wood Quality, Useful Area for Planting, Eucalyptus Genetic Materials, Harvesting Age

et al. 2019, Resquin et al. 2019, Souza et al. 2020).

The planting spacing can cause changes in wood properties, by interfering in the growth and in the morphology of the trees, depending on the age of their evaluation (Hébert et al. 2016, Rocha et al. 2016). Each species, clone or variety has a peculiar behavior under the growth conditions imposed by the planting spacing. In crops of rapid growth and short cycle of rotation, such as those of the genus Eucalyptus, the study of the properties of wood is even more relevant, due to the higher proportion of juvenile wood in the trunk and its various uses (Karlsson et al. 2013, Eisenbies et al. 2017, Pachas et al. 2019).

Studies that report the influence of spacing on the properties of Eucalyptus wood concentrate basically on the basic density of the wood (Alcorn et al. 2007, Lasserre et al. 2009, Moulin et al. 2017), and the knowledge on information that precisely addresses the impact of planting spacing of young trees on the anatomy and chemical composition of wood is incipient. Although the short rotation periods provide greater volumes of wood, it is essential to guarantee conditions that allow the proper establishment of the forest crop (Resquin et al. 2019), and consequently, quality wood.

In view of the need to meet the high demand for pulpwood and energy and the costs involved in maintaining and growing the forest, companies in this sector experiment and invest in dense plantations and in short-cycle rotations (less than 7 years), a characteristic of Brazilian forestry. The ob- jective of this research work was to evaluate the influence of planting spacing on the wood properties of Eucalyptus clones in short-cycle plantations.

\section{Material and methods}

\section{Material and sampling}

Two clones of Eucalyptus grandis and one clone of Eucalyptus grandis $\times$ Eucalyptus urophylla from experimental plantations, located in Paranapanema, São Paulo state, Brazil, were studied $\left(23^{\circ} 23^{\prime} 19^{\prime \prime} \mathrm{S}, 48^{\circ} 43^{\prime}\right.$ $22^{\prime \prime}$ W; elevation $610 \mathrm{~m}$ a.s.l.). The average annual precipitation during cultivation (2010-2014) was $1300 \mathrm{~mm}$ and the average annual temperature was $20^{\circ} \mathrm{C}$. The soil was classified as a Latossolo Vermelho (Oxisol). The eucalyptus clones were planted at four planting spacings $(3 \times 1,3 \times 2,3 \times 3$ and $3 \times 4 \mathrm{~m})$ and 48 trees were felled, 16 of each clone, i.e., four trees per spacing (Tab. 1). The trees were harvested within the plot previously defined in the experimental design to eliminate the edge effects. After cutting, the wood volume of each tree was estimated using the Smalian method. Six $3-\mathrm{cm}$ thick wooden disks were removed from each tree in the positions: $1.3 \mathrm{~m}$ from the ground (DBH) and 0, 25, 50, 75 and $100 \%$ of the commercial height (Fig. 1).

\section{Analysis of wood properties}

Two opposite wooden wedges per disk, from the positions sampled along the trunk (Fig. 1), were immersed in water for saturation and the average basic density of the wood was obtained according to Associ- 
Tab. 1 - Experimental plot area, tree diameter and commercial height averages by genetic material and spacing. $(\mathrm{N})$ : number of trees in the useful plot (no edge effect); (DBH): diameter at breast height $(\mathrm{cm}) ;(\mathrm{CH})$ : commercial height $(\mathrm{m})$.

\begin{tabular}{ccccccccc}
\hline $\begin{array}{c}\text { Useful } \\
\text { area }\end{array}$ & $\begin{array}{c}\text { Plot } \\
\text { area }\end{array}$ & $\mathbf{N}$ & \multicolumn{2}{c}{$\begin{array}{c}\text { E. grandis } \\
\text { (clone A) }\end{array}$} & \multicolumn{2}{c}{$\begin{array}{c}\text { E. grandis } \\
\text { (clone B) }\end{array}$} & \multicolumn{2}{c}{$\begin{array}{c}\text { E. grandis } \times \\
\text { E. urophylla }\end{array}$} \\
\cline { 5 - 10 }$\left(\mathbf{m}^{2}\right)$ & & DBH & CH & DBH & CH & DBH & CH \\
\hline 3 & 300 & 36 & 11.8 & 15.0 & 12.8 & 15.7 & 12.1 & 12.4 \\
\hline 6 & 600 & 36 & 14.6 & 18.9 & 15.5 & 19.2 & 15.1 & 17.1 \\
\hline 9 & 900 & 36 & 16.1 & 19.7 & 18.2 & 21.9 & 17.3 & 18.3 \\
\hline 12 & 1200 & 36 & 17.3 & 19.4 & 20.8 & 23.0 & 20.3 & 20.5 \\
\hline
\end{tabular}

ação Brasileira de Normas Técnicas (Brazilian National Standards Organization) NBR 11941 (ABNT 2003). Then the dry mass of wood of each tree without bark and per hectare ( $\mathrm{t}$ ) was estimated according to eqn. 1:

$$
D M=\frac{V \cdot B D}{1000}
$$

where $D M$ is the dry mass of wood $(t), V$ is the volume of tree without bark $\left(\mathrm{m}^{3}\right), B D$ is the basic wood density $\left(\mathrm{kg} \mathrm{m}^{-3}\right)$.

The anatomical measurement of the vessels and fibers was performed on samples with dimensions of $1.0 \times 1.5 \times 2.0 \mathrm{~cm}$ taken from the DBH disks, in the peripheral region of the heartwood according to the Comisión Panamericana de Normas Técnicas (COPANT 1974). To determine the diameter, frequency and area of vessels, 20- $\mu \mathrm{m}$ thick transverse histological sections were performed on the samples. Then, the samples were transformed into chips to prepare the macerate (Ramalho 1987). After assembling the anatomical slides with the macerated material, they were photomicrographed by a digital camera coupled to the microscope, and the length, width and diameter of the fiber lumen (20 repetitions) were directly measured using the software Axiovision $^{\circledast}$ v. 4.5 (Carl Zeiss Microscopy LLC, White Plains, NY, USA). The thickness of the fiber wall was calculated indirectly by the difference between the width and diameter of the fiber lumen, divided by two, and the wall fraction was de- termined by the relationship between the wall thickness and the width of the fibers.

Two opposite wooden wedges were broken up into chips, and then they were transformed into sawdust homogenized in 40 and 60 mesh screens. The sawdust retained on the 60 mesh was subjected to chemical analysis to determine the extracts by dissolution in acetone solvent as provided by the Technical Association of the Pulp and Paper Industry (TAPPI 2006). Soluble lignin was determined by the methodology developed by Gomide \& Demuner (1986) and insoluble lignin by the equation described in Goldschimid (1971). Total lignin was quantified by the sum of the soluble and insoluble fractions. Ash content of the wood was quantified according to the methodology of NBR 8112 (ABNT 1983) and the higher heating value of the wood according to the standard NBR 8633 (ABNT 1984).

\section{Data analysis}

The experiment was conducted in a completely randomized design. The data were initially tested for homogeneity of variance and normality of the experimental errors using the Cochran and Shapiro-Wilk tests, respectively. Subsequently, linear regression analyses were performed to analyze the effect of the useful area (independent variable) of the four spacings $(3 \times 1,3 \times 2,3 \times 3$ and $3 \times 4 \mathrm{~m}$ ) on the quantitative properties of the wood (dependent variable) of the three investigated eucalyptus clones.

\section{Results and discussion}

The highest values of basic wood density were detected at the largest spacing. Between the $3 \times 1$ and $3 \times 4 \mathrm{~m}$ spacing, the percentage increments were $2.2 \%$ ( $E$. grandis clone A), $7.0 \%$ (E. grandis clone B) and 7.5\% (E. grandis $\times$ E. urophylla - Tab. 2) .

The increments in the basic density values are due to the different planting spacings, which caused different effects on each of the eucalyptus clones, even under similar silvicultural conditions. However, the difference in useful area from the smallest to the largest spacing is small and the age of evaluation of the material was only 4 years. These differences may be more evident in the evaluation of materials at older ages, when the level of competition between trees in the field has greater effects on growth and, consequently, on the properties of wood.

Density is one of the characteristics of wood that has a high heritability (Lasserre et al. 2009, Fernandes et al. 2011), which explains the low variation (less than 10\%) of this property between the smallest and the largest spacing in the genetic materials evaluated. The absence of variation in the basic density of wood in useful areas from 6 to $16 \mathrm{~m}^{2}$ was observed for $E$. benthamii at the age 6 years (Benin et al. 2017); and in areas from 3 to $4.5 \mathrm{~m}^{2}$ for $E$. grandis at the ages of 1, 3 and 5 years (Eloy et al. 2016).

Some references indicate a small increase in density as a function of planting spacing in eucalyptus stands (Feuchard 2015, Rocha et al. 2016, Moulin et al. 2017, Teixeira et al. 2020). However, considering the multiple uses of wood, the increase in density impacts the production and economy of the forest-based sector (Lasserre et al. 2009, Pachas et al. 2019). The effect of the useful area of the trees, resulting from the spacing, was significant when analyzing the adjusted models of the basic density of the wood, with a total variation between 39\% (E. grandis clone B) and $53 \%$ (E. grandis $\times E$. urophylla), as shown in Tab. 3. The relationship of the wood density of trees of the three genetic materials by useful area is shown in Fig. $2 \mathrm{~A}$.

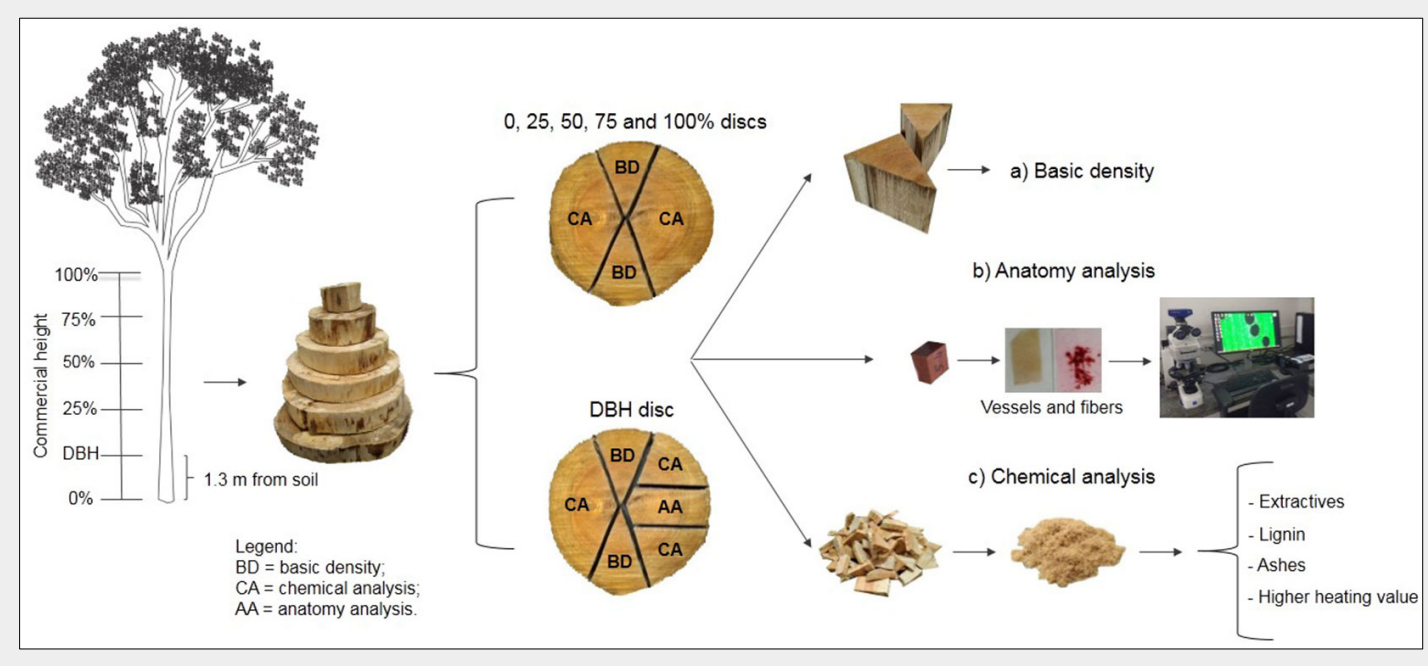

Fig. 1 - Scheme of tree sampling, with demarcation of the positions of removal of the disks and specifications for the technological analysis. 
Tab. 2 - Physical properties, anatomical structure and chemical composition of wood from Eucalyptus clones at different planting spacings. (BD): basic density; $\left(D_{\text {tree }}\right)$ : dry mass per tree; $\left(D_{\text {ha }}\right)$ : dry mass per hectare; (FL): fiber length; (FWt): fiber wall thickness; (WF): wall fraction; (VD): Vessel diameter; (VF): Vessel frequency; (VA): Vessel area; (Ext): Extractive content; (Lig): Lignin content; (Ash): Ash content; (HHV): Higher heating value.

\begin{tabular}{|c|c|c|c|c|c|c|c|c|c|c|c|c|}
\hline \multirow{2}{*}{$\begin{array}{l}\text { Species } \\
\text { Useful area }\left(\mathrm{m}^{2}\right)\end{array}$} & \multicolumn{4}{|c|}{$\begin{array}{l}\text { E. grandis } \\
\text { (clone A) }\end{array}$} & \multicolumn{4}{|c|}{$\begin{array}{l}\text { E. grandis } \\
\text { (clone B) }\end{array}$} & \multicolumn{4}{|c|}{$\begin{array}{l}\text { E. grandis } \times \\
\text { E. urophylla }\end{array}$} \\
\hline & 3 & 6 & 9 & 12 & 3 & 6 & 9 & 12 & 3 & 6 & 9 & 12 \\
\hline $\mathrm{BD}\left(\mathrm{g} \mathrm{cm}^{-3}\right)$ & 0.46 & 0.49 & 0.5 & 0.47 & 0.43 & 0.44 & 0.46 & 0.46 & 0.4 & 0.41 & 0.42 & 0.43 \\
\hline $\mathrm{DM}_{\text {tree }}(\mathrm{t})$ & 0.039 & 0.074 & 0.094 & 0.092 & 0.042 & 0.075 & 0.118 & 0.147 & 0.029 & 0.059 & 0.08 & 0.112 \\
\hline $\mathrm{DM}_{\mathrm{ha}}(\mathrm{t})$ & 131.5 & 123 & 104.5 & 76.5 & 141.3 & 124.7 & 131.5 & 122.5 & 96.6 & 97.8 & 89.4 & 93.4 \\
\hline $\mathrm{FL}(\mu \mathrm{m})$ & 961 & 988 & 973 & 973 & 945 & 932 & 935 & 964 & 948 & 1010 & 986 & 960 \\
\hline FWt $(\mu \mathrm{m})$ & 3.16 & 3.04 & 3 & 2.77 & 2.52 & 2.33 & 2.46 & 2.31 & 2.61 & 2.7 & 2.66 & 2.68 \\
\hline WF (\%) & 36.97 & 36.97 & 37.59 & 33.33 & 30.06 & 29.47 & 29.4 & 26.48 & 29.69 & 29.15 & 28.27 & 28.26 \\
\hline $\mathrm{VD}(\mu \mathrm{m})$ & 101.12 & 116.75 & 109.75 & 111.04 & 94.49 & 99.1 & 96.98 & 99.62 & 100.74 & 113.22 & 117.74 & 115.86 \\
\hline VF $\left(n m^{-1}\right)$ & 10.09 & 8.84 & 8.98 & 9.19 & 12.9 & 11.89 & 11.6 & 10.48 & 10.28 & 8.68 & 8.55 & 8.54 \\
\hline $\mathrm{VA}\left(\mathrm{mm}^{2}\right)$ & 80.87 & 94.67 & 85.28 & 88.39 & 90.55 & 91.65 & 85.62 & 81.52 & 81.17 & 87.33 & 93.17 & 89.83 \\
\hline Ext (\%) & 1.14 & 1.12 & 1.13 & 1.29 & 1.42 & 1.29 & 1.14 & 1.08 & 0.79 & 1.13 & 0.88 & 0.94 \\
\hline Lig (\%) & 27.24 & 27.4 & 26.77 & 27.79 & 28.6 & 28.01 & 28.02 & 28.35 & 26.52 & 28.94 & 28.04 & 28.26 \\
\hline Ash (\%) & 0.45 & 0.4 & 0.37 & 0.45 & 0.44 & 0.49 & 0.47 & 0.52 & 0.63 & 0.59 & 0.67 & 0.6 \\
\hline $\mathrm{HHV}\left(\mathrm{kcal} \mathrm{kg}^{-1}\right)$ & 4406 & 4320 & 4417 & 4380 & 4423 & 4409 & 4427 & 4466 & 4337 & 4389 & 4421 & 4442 \\
\hline
\end{tabular}

The amount of dry wood mass per tree of each eucalyptus clone studied was influenced by the spacing (Tab. 2). Regardless of the clone, wider spacing provided a greater amount of dry mass (Tab. 3, Fig. $2 \mathrm{~B})$, as the larger useful area favors the volumetric increase per tree.

There are increases of 53,105 and $83 \mathrm{~kg}$ of dry wood mass per tree, from the $3 \times 1$ to the $3 \times 4 \mathrm{~m}$ spacing in $\mathrm{E}$. grandis (clone A); $\mathrm{E}$. grandis (clone B) and E. grandis $\times$ E. urophylla, respectively (Tab. 2). This highlights the specificity of each genetic material given the variation in planting spacing. The greater planting spacing increases the proportion of wood per tree, contributing to management practices and to the production sectors (Lasserre et al. 2005, 2009). The greater planting spacing $(3 \times 4 \mathrm{~m})$ resulted in the largest amount of dry mass per tree, since the largest useful area favors individual growth in diameter and height (Tab. 1). The smallest spacing contributed to the largest amount of dry mass per hectare, due to the greater competition between tree individuals. The useful area resulting from the planting spacing significantly explained approximately $75 \%$ of the dry mass production of wood per hectare for E. grandis (clone A - Tab. 3).

Tab. 3 - Statistical parameters of fitted models to estimate basic density, dry mass, vessel diameter, vessel frequency and fiber wall thickness of wood as a function of the useful area per tree for the three Eucalyptus clones. (Bd): Basic density; (UA): useful area; $(\mathrm{Dm})$ : Dry mass; (Vd): vessel diameter; (Vf): vessel frequency; (FWt): fiber wall thickness; (ns): not significant; (**): significant at $1 \%$ by the $\mathrm{F}$ test for regression and $\mathrm{t}$ for coefficients of equation.

\begin{tabular}{|c|c|c|c|c|}
\hline Properties & $\begin{array}{l}\text { Statistical } \\
\text { parameters }\end{array}$ & E. grandis (clone A) & E. grandis (clone A) & E. grandis $\times E$. urophylla \\
\hline \multirow[t]{3}{*}{ Basic density } & Equation & $\mathrm{Bd}=0.470+0.001 \cdot \mathrm{UA}$ & $\mathrm{Bd}=0.424+0.003 \cdot \mathrm{UA}$ & $\mathrm{Bd}=0.389+0.003 \cdot \mathrm{UA}$ \\
\hline & $\mathrm{R}^{2}$ & $0.020^{\mathrm{ns}}$ & $0.391^{* *}$ & $0.530 * *$ \\
\hline & $S_{y x}$ & 0.031 & 0.015 & 0.011 \\
\hline \multirow[t]{3}{*}{ Dry mass per tree } & Equation & $\mathrm{Dm}=0.031+0.006 \cdot \mathrm{UA}$ & $\mathrm{Dm}=0.006+0.012 \cdot \mathrm{UA}$ & $\mathrm{Dm}=0.002+0.009 \cdot \mathrm{UA}$ \\
\hline & $\mathrm{R}^{2}$ & $0.714^{* *}$ & $0.978 * *$ & $0.964^{* *}$ \\
\hline & $S_{y x}$ & 0.013 & 0.006 & 0.006 \\
\hline \multirow[t]{3}{*}{ Dry mass per hectare } & Equation & $\mathrm{Dm}=154.8-6.12 \cdot \mathrm{UA}$ & $\mathrm{Dm}=142.4-1.66 \cdot \mathrm{UA}$ & $\mathrm{Dm}=98.74-0.59 \cdot \mathrm{UA}$ \\
\hline & $\mathrm{R}^{2}$ & $0.747^{* *}$ & $0.264^{\text {ns }}$ & $0.040^{\text {ns }}$ \\
\hline & $S_{y x}$ & 12.79 & 9.93 & 10.45 \\
\hline \multirow[t]{3}{*}{ Vessel diameter } & Equation & $V d=104.0+0.759 \cdot U A$ & $\mathrm{Vd}=94.2+0.442 \cdot \mathrm{UA}$ & $\mathrm{Vd}=99.4+1.663 \cdot \mathrm{UA}$ \\
\hline & $\mathrm{R}^{2}$ & $0.104^{\mathrm{ns}}$ & $0.062^{\mathrm{ns}}$ & $0.433^{* *}$ \\
\hline & $S_{y x}$ & 7.97 & 6.19 & 6.82 \\
\hline \multirow[t]{3}{*}{ Vessel frequency } & Equation & $V f=9.91-0.085 \cdot U A$ & $V f=13.61-0.252 \cdot U A$ & $V f=10.34-0.178 \cdot U A$ \\
\hline & $\mathrm{R}^{2}$ & $0.115^{\mathrm{ns}}$ & $0.501^{* *}$ & $0.230^{\mathrm{ns}}$ \\
\hline & $S_{y x}$ & 0.85 & 0.90 & 1.16 \\
\hline \multirow[t]{3}{*}{ Fiber wall thickness } & Equation & $\mathrm{FWt}=3.29-0.040 \cdot \mathrm{UA}$ & $\mathrm{FWt}=2.53-0.017 \cdot \mathrm{UA}$ & $\mathrm{FWt}=2.62+0.005 \cdot \mathrm{UA}$ \\
\hline & $\mathrm{R}^{2}$ & $0.450 * *$ & $0.060^{\text {ns }}$ & $0.015^{\mathrm{ns}}$ \\
\hline & $S_{y x}$ & 0.16 & 0.24 & 0.15 \\
\hline
\end{tabular}




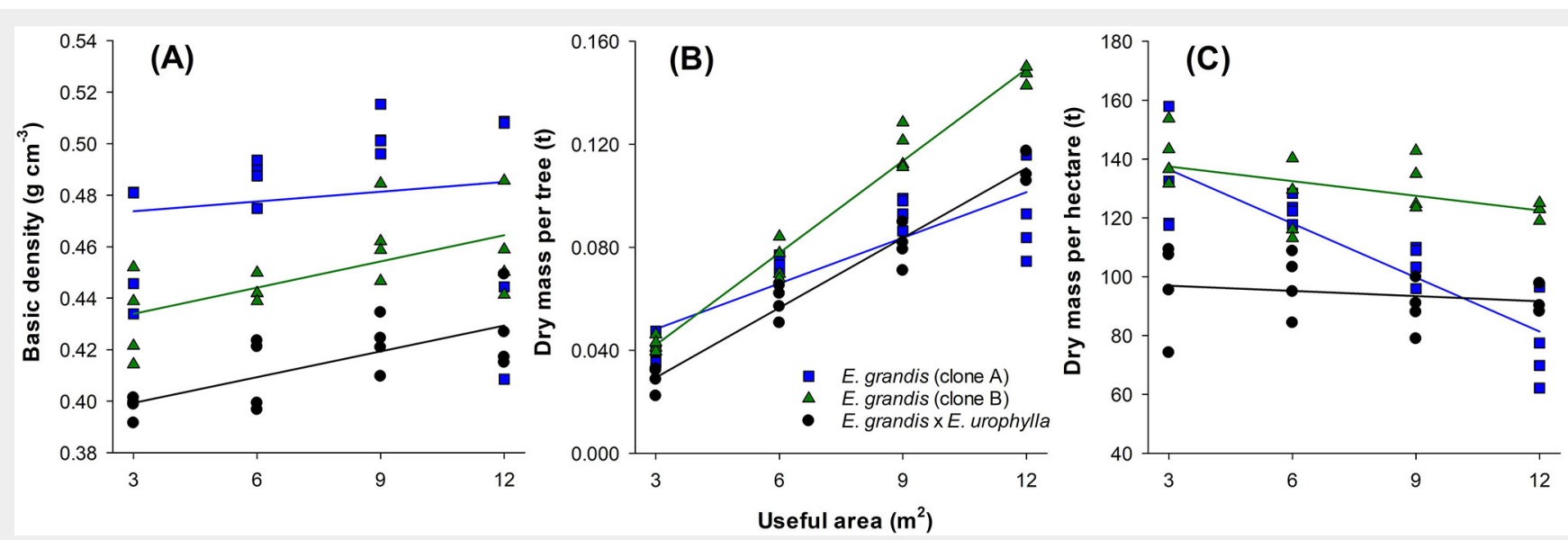

Fig. 2 - Scatterplots of basic density (A), dry mass of the wood per tree (B) and per hectare (C) as a function of the useful area per tree for the three Eucalyptus clones.

The largest amount of dry mass per area was concentrated at the denser spacing (Fig. 2C), corroborating with that found for E. grandis $\times$ E. urophylla aged approximately 3 years (Torres et al. 2016) and E. grandis at 10 years of age (Goulart et al. 2003).

Compared to the other clones, E. grandis (clone $A$ ) showed the most marked reduction in the amount of dry mass per area $(t$ $\mathrm{ha}^{-1}$ ) as the planting spacing increased (Fig. $2 C)$. This behavior can be associated with the fact that this clone has the highest density values and the lowest values of solid volume of wood, leading to a decreasing trend between the growth rate of trees and the basic density of eucalyptus wood. Despite being an important factor since the $19^{\text {th }}$ century, the influence of the useful area of the planting spacing on the dimensions of the woody anatomical cells, on the angle of the microfibrils and on the density is still poorly understood (Watson et al. 2003, Guedes et al. 2018), mainly for tropical woods at a young age.

Only the diameter and frequency of vessels and the wall thickness of the fibers, among the anatomical elements, were influenced by the planting spacing in at least one of the three eucalyptus clones evaluated. The vessel area and the length and fraction of the fiber wall (Tab. 2) were not susceptible to variations in spacing in any of the studied clones. The diameter of wood vessels tended to increase as the planting spacing between trees increased. However, the effect was significant only for the E. grandis $\times$ E. urophylla clone, with $43 \%$ variation (Tab. 3, Fig. 3A), whereas the other two clones showed $15 \%$ increase in vessel dimensions from $3 \times 1 \mathrm{~m}$ to $3 \times 4 \mathrm{~m}$. Increases in the diameters of the anatomical vessels of $E$. grandis $x E$. urophylla with the planting spacing have been reported in the literature: (i) $3.3 \%$ from $3 \times 1$ to $3 \times 4 \mathrm{~m}$ at 4 and 5 years old (Feuchard 2015); and (ii) $4.8 \%$ from $2 \times 3$ to $10 \times 2 \mathrm{~m}$ at 4 years and 6 months of age (Guedes et al. 2018).

The frequency of anatomical vessels decreased with the increase in planting spacing in the wood of the three clones, being significant only in E. grandis (clone B). The explained variation was $50 \%$ between the spacing and the number of vessels per $\mathrm{mm}^{2}$ (Tab. 3, Fig. 3B), with an $18.8 \%$ reduction from the spacing of $3 \times 1$ to $3 \times 4 \mathrm{~m}$. A decrease of $16.8 \%$ in vessel frequency with the increase the useful area was observed for E. grandis $\times$ E. urophylla at the ages of 4 and 5 years (Feuchard 2015). For this same species, at the ages of 4 years and 6 months, the increase in the useful area led to a $5.9 \%$ increment in this variable (Guedes et al. 2018). The anatomical vascular area was not influenced by the planting spacing, despite the tendency to increase the diameter and reduce the frequency of vessels (Fig. 3A, Fig. 3B). In young eucalyptus trees, changes in the useful area did not compromise the conduction of liquids in the trunk, and a similar behavior was observed by Nath et al. (2016). However, the reduction in the frequency of anatomical vessels with the increase in the useful area for $E$. grandis (clone B) and $E$. grandis $\times E$. urophylla trees may have contributed to the increase observed in the basic density of the wood.

The variation in the wall thickness of the E. grandis fibers (clone A) was explained $\left(R^{2}=45 \%\right)$ by the useful area, but for the other eucalyptus clones the same effect was not observed (Tab. 3, Fig. 3C). In the woods of the $E$. grandis clones, the wall thickness decreased with the increase in
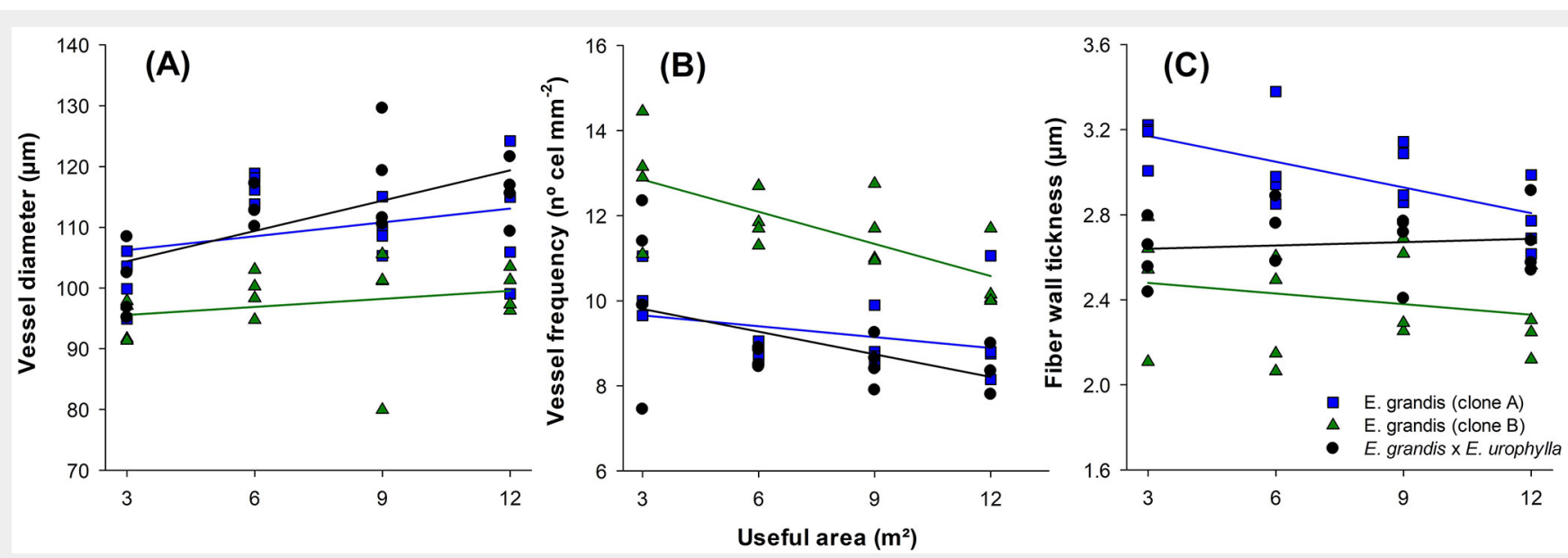

Fig. 3 - Scatterplots of vessel diameter (A), vessel frequency (B) and fiber wall thickness (C) as a function of the useful area per tree for the three Eucalyptus clones. 
the planting spacing of the trees, while in the hybrid $E$. grandis $\times E$. urophylla it increased in absolute values of $2.8 \%$ in the dimensions of the fibers from the spacing of $3 \times 1$ to $3 \times 4 \mathrm{~m}$ (Tab. 2). The change of $14 \mathrm{~m}^{2}$ in the useful areas of the spacing led to a small increase of $1.3 \%$ in the fiber wall thickness of E. grandis $\times E$. urophylla, at 4 years and 6 months of age (Guedes et al. 2018).

Cell wall thickness is associated with genetic and environmental factors and the age of the tree (Silva et al. 2007, Lasserre et al. 2009). This can cause impacts on the wood properties such as the basic density and modulus of elasticity, compromising the application of this material for certain uses (Moore et al. 2009, Rocha et al. 2016). The young age of the evaluated clones (4 years old) did not allow anatomical distinc tion of the wood when varying the plant ing spacing between trees, resulting in little or no effect on the morphology of the vessels and wood fibers (Tab. 2). In gen eral, moderate to low variability in anatom ical properties indicates that they may be under genetic control and, therefore, be less affected by the environment and com petition between trees than the characteristics of growth and productivity (Gort et al. 2009).

The useful area did not affect the chemical composition, extractive and lignin contents, ash content and higher heating value of the wood of the evaluated eucalyptus clones (Tab. 2). Absence of a pattern in the relationship of ash content, extractives content and lignin content and of the higher heating value with planting spacing (useful areas of 3, 4.5 and $6 \mathrm{~m}^{2}$ ) was also observed for eucalyptus clones at 6 years of age (Elerati 2017).

The extractives content showed small variations when considering clones and planting spacing. The content of extractives in wood contributes to the increase in the higher heating value (when there are phenols in its composition) and in the carbon content, which are interesting factors for energy use and the scope of climate changes in carbon capture and storage. Similarly, lignin content and higher heating value did not show significant evidence of the effect of planting spacing. The lignin content showed lower results than those observed for eucalyptus clones for power generation, which ranged from $27 \%$ to $33 \%$ (Carneiro et al. 2017, Castro et al. 2013). However, it is important to consider that the materials are individuals considered young, which still undergo a process of physiological maturation.

Regarding the ash content, there was no significant effect of planting spacing (Tab. 2). Woods grown in neotropical regions have a high variation in ash content, this value being higher in hardwoods and younger trees. In eucalyptus woods there is a trend of reduction in the ash content with increasing age. This may be related to the decrease in the physiological activity of the tree (Protásio et al. 2014). Higher heat- ing value (HHV) is influenced by the intrinsic characteristics of the species, such as the content and type of extracts present in the wood, which can contribute to the amount of heat released during the combustion of the material and influence the energy capacity of the fuel. The HHV detected in the wood of the studied clones was close to the average found for different eucalyptus clones destined for energy (4538 kcal kg-1 - Brand \& Muniz 2010, Santos et al. 2016).

As observed in this study, the higher heating value of the wood did not show a direct relationship with the useful area of the trees of Eucalyptus urophylla $\times E$. grandis (clones GG 100 and GG 680) and E. urophylla (clone GG 157) at 2 years and 8 months of age (Teixeira et al. 2020). Each evaluated clone had an increase in this energy property within certain amplitudes of variation in spacing.

The proportion of chemical components in wood depends on many factors, the influence of genetic material being very strong, in addition to the tree age (Moulin et al. 2015, Rocha et al. 2016). It is important to highlight that, in some uses of wood in combustion, high levels of ash can cause corrosion and incrustations in metallic equipment, reducing factory productivity (Jardim et al. 2017) and decreasing the energy calorific value. The small influence of the planting spacing on the wood properties of the studied Eucalyptus clones provides insights for the planting of forest stands at reduced spacing, without losses in the quality of the young wood produced (Lasserre et al. 2009). These mechanisms can maximize land use, if economically viable and operationally possible.

\section{Conclusion}

The wood properties of eucalyptus genetic materials in short rotation were altered by planting spacing in different ways, but with little intensity. Density, a property that affects different uses of wood, was influenced by the different useful areas, even in young wood.

\section{Acknowledgments}

We thank the company Suzano S.A., São Paulo, Brazil for its assistance in conducting the research, to the Espírito Santo Research Support Foundation (FAPES) and the Coordination for the Improvement of Higher Education Personnel (CAPES) for granting the scholarships.

\section{References}

Alcorn PJ, Pyttel P, Bauhus J, Smith RGB, Thomas D, James R, Nicotra A (2007). Effects of initial planting density on branch development in 4-year-old plantation grown Eucalyptus pilularis and Eucalyptus cloeziana trees. Forest Ecology and Management 252: 41-51. - doi: 10.1016/j. forec0.2007.06.021

ABNT (1983). NBR 8112: Carvão vegetal - análise imediata [NBR 8112: Charcoal - immediate analysis]. Associação Brasileira de Normas Técnicas,
Rio de Janeiro, Brazil, pp. 1-5. [in Portuguese] ABNT (1984). NBR 8633: Carvão vegetal - determinação do poder calorífico [NBR 8633: Charcoal - determination of heating value]. Associação Brasileira de Normas Técnicas, Rio de Janeiro, Brazil, pp. 1-13. [in Portuguese]

ABNT (2003). NBR 11941: Madeira - determinação da densidade básica [NBR 11941: Wood - Determination of basic density]. Associação Brasileira de Normas Técnicas, Rio de Janeiro, Brazil, pp. 1-6. [in Portuguese]

Benin CC, Watzlawick LF, Hillig E (2017). Propriedades físicas e mecnicas da madeira de Eucalyptus benthamii sob efeito do espaçamento de plantio [Physical and mechanical properties of Eucalyptus benthamii wood under the effect of planting spacing]. Ciência Florestal 27 (4): 1375-1384. [in Portuguese] - doi: 10.5902/19805 09830219

Brand MA, Muniz GIB (2010). Influência da época de colheita da biomassa florestal sobre sua qualidade para a geração de energia [Influence of the harvest season over the quality of wood fuel]. Scientia Forestalis 38 (88): 619-628. [in Portuguese]

Brito AS, Vidaurre GB, Oliveira JTS, Silva JGM, Rodrigues BP, Carneiro ACO (2019). Effect of planting spacing in production and permeability of heartwood and sapwood of eucalyptus wood. Floresta e Ambiente 26 (1): e20180378. doi: 10.1590/2179-8087.037818

Carneiro ACO, Vital BR, Frederico PGU, Figueiró CG, Fialho LF, Silva CMS (2017). Caracterização energética das madeiras de clones de Eucalyptus cultivados em diferentes localidades [Energetic characterization of the wood from Eucalyptus clones grown in different localities]. Brazilian Journal of Wood Science 8 (3): 127-135. [in Portuguese] - doi: 10.12953/2177-6830/rcm.v8n3 p127-135

Castro AFNM, Castro RVO, Carneiro ACO, Lima JE, Santos RC, Pereira BLC, Alves ICN (2013). Análise multivariada para seleção de clones de eucalipto destinados à produção de carvão vegetal [Multivariate analysis for the selection of eucalyptus clones destined for charcoal production]. Pesquisa Agropecuária Brasileira 48 (6): 627-635. [in Portuguese] - doi: 10.1590/So 100-204X2013000600008

COPANT (1974). Descripción de características generales, macroscópicas de las maderas angiospermas dicotiledôneas [Description of general, macroscopic characteristics of dicotyledonous angiosperm woods]. Comisión Panamericana de Normas Técnicas, La Paz, Bolivia, pp. 1-19. [in Spanish]

Eisenbies MH, Volk TA, Espinoza J, Gantz C, Himes A, Posselius J, Shuren R, Stanton B, Summers B (2017). Biomass, spacing and planting design influence cut-and-chip harvesting in hybrid poplar. Biomass and Bioenergy 106: 182190. - doi: 10.1016/j.biombioe.2017.09.003

Elerati TL (2017). Espaçamento, genótipo, idade e a produção de biomassa em povoamentos de eucalipto [Spacing, genotype, age and biomass production in eucalypt stands]. Dissertação, Departamento de Engenharia Florestal, Universidade Federal de Viçosa, Viçosa, MG, Brazil, pp. 90. [in Portuguese]

Eloy E, Silva DA, Schmidt D, Trevisan R, Caron BO, Elli EF (2016). Effect of planting age and 
spacing on energy properties of Eucalyptus grandis W. Hill EX Maiden. Revista Árvore 40 (4): 749-758. - doi: 10.1590/0100-676220160004 00019

Fernandes DE, Gomide JL, Colodette JL, Ferreira MZ (2011). Influência da produtividade de clones híbridos de eucalipto na densidade da madeira e na polpação Kraft [Influence of eucalypt hybrid clones productivity on wood basic density and kraft pulping yield]. Scientia Forestalis 39 (90): 143-150. [in Portuguese]

Feuchard LD (2015). Influência do espaçamento de plantio e idade de colheita na qualidade da madeira de eucalipto para celulose [Influence of planting space and harvest age on eucalypt wood quality for pulpwood]. Dissertação, Departamento de Ciências Florestais e da Madeira, Universidade Federal do Espírito Santo, Jerônimo Monteiro, ES, Brazil, pp. 42. [in Portuguese]

Goldschimid O (1971). Ultraviolet spectra. In: "Lignins" (Sarkanen KV, Ludwing CH eds). Wiley Interscience, New York, USA, pp. 241-266.

Gomide JL, Demuner BJ (1986). Determinação do teor de lignina em material lenhoso: método Klason modificado [Determination of lignin content in woody material: modified Klason method]. O Papel 47 (8): 36-38. [in Portuguese] Gort J, Gerendiain AZ, Peltola H, Pulkkinen P, Routa J, Jaatinen R (2009). Differences in fibre properties in Scots pine (Pinus sylvestris L.) genetic entries grown at different spacing and sites. Silva Fennica 43 (3): 355-368. - doi: 10.1421 4/sf.193

Goulart M, Haselein R, Hoppe JM, Farias JA, Pauleski DT (2003). Massa específica básica e massa seca de madeira de Eucalyptus grandis sob o efeito do espaçamento de plantio e da posição axial no tronco [Basic density and dry mass of wood of Eucalyptus grandis as affected by tree spacing and trunk position]. Ciência Florestal 13 (2): 167-175. [in Portuguese] - doi: $10.5902 / 198050981753$

Guedes TO, Lima LC, Hein PRG, Silva JRM, Santos LDT (2018). Effect of planting density on wood anatomy in Eucalyptus and Acacia from Brazil. Madera y Bosques 24 (2): e2421420. - doi: 10.21829/myb.2018.2421420

Hébert F, Krause C, Plourde PY, Achim A, Prégent $G$, Ménétrier J (2016). Effect of tree spacing on tree level volume growth, morphology, and wood properties in a 25 -year-old Pinus banksiana plantation in the boreal forest of Quebec. Forests 7 (276): 11-16. - doi: 10.3390/f71 10276

Jardim JM, Gomes FJB, Colodette JL, Brahim BP (2017). Avaliação da qualidade e desempenho de clones de eucalipto na produção de celulose [Evaluation of the quality and performance of eucalyptus clones in cellulose production]. $O$ Papel 78 (11): 122-129. [in Portuguese]

Karlsson L, Mörling T, Bergsten U (2013). Influence of silvicultural regimes on the volume and proportion of juvenile and mature wood in bo- real Scots pine. Silva Fennica 47: 1-17. - doi: 10.14214/sf.938

Lasserre JP, Mason EG, Watt MS (2005). The effects of genotype and spacing on Pinus radiata [D. Don] corewood stiffness in an 11-year old experiment. Forest Ecology and Management 205: 375-383. - doi: 10.1016/j.foreco.2004.10.037 Lasserre JP, Mason EG, Watt MS, Moore JR (2009). Influence of initial planting spacing and genotype on microfibril angle, wood density, fibre properties and modulus of elasticity in Pinus radiata D. Don corewood. Forest Ecology and Management 258: 1924-1931. - doi: 10.1016/ j.foreco.2009.07.028

Moore J, Achim A, Lyon A, Mochan S, Gardiner B (2009). Effects of early re-spacing on the physical and mechanical properties of Sitka spruce structural timber. Forest Ecology and Management 258: 1174-1180. - doi: 10.1016/j.foreco.2009. 06.009

Moulin JC, Arantes MDC, Vidaurre GB, Paes JB, Carneiro ACO (2015). Efeito do espaçamento, da idade e da irrigação nos componentes químicos da madeira de eucalipto [Effect of spacing, age and irrigation on chemical components of Eucalyptus wood]. Revista Árvore 39 (1): 199208. [in Portuguese] - doi: 10.1590/0100-676220 15000100019

Moulin JC, Rocha MFV, Arantes MDC, Boschetti WTN, Jesus MS, Trugilho PF (2017). Influência do espaçamento de plantio e irrigação na densidade e na massa seca em espécies de Eucalyptus [The influence of plant spacing and irrigation on density and dry mass on Eucalyptus species]. Nativa 5: 367-371. [in Portuguese] doi: 10.5935/2318-7670.v05no5a11

Nath CD, Munoz F, Pélissier R, Burslem DFRP, Muthusankar G (2016). Growth rings in tropical trees: role of functional traits, environment, and phylogeny. Trees 30: 2153-2175. - doi: 10.100 7/s00468-016-1442-1

Pachas ANA, Sakanphet S, Soukkhy O, Lao M, Savathvong S, Newby JC, Souliyasack B, Keoboualapha B, Dieters MJ (2019). Initial spacing of teak (Tectona grandis) in northern Lao PDR: impacts on the growth of teak and companion crops. Forest Ecology and Management 435: 77-88. - doi: 10.1016/j.foreco.2018.12.031

Protásio TP, Goulart SL, Neves TA, Trugilho PF, Ramalho FMG, Queiroz LMSB (2014). Qualidade da madeira e do carvão vegetal oriundos de floresta plantada em Minas Gerais [Wood and charcoal quality from planted forest in Minas Gerais State, Brazil]. Pesquisa Florestal Brasileira 34 (78): 111-123. [in Portuguese] - doi: 10.433 6/2014.pfb.34.78.657

Ramalho RS (1987). O uso de macerado no estudo anatômico de madeira [The use of macerate in the anatomical study of wood]. UFV, Viçosa, Brazil, pp. 4. [in Portuguese]

Resquin F, Navarro-Cerrillo RM, Carrasco-Letelier L, Casnati CR (2019). Influence of contrasting stocking densities on the dynamics of aboveground biomass and wood density of Eucalyp- tus benthamii, Eucalyptus dunnii, and Eucalyptus grandis for bioenergy in Uruguay. Forest Ecology and Management 438: 63-74. - doi: 10.1016/j.foreco.2019.02.007

Rocha MFV, Vital BR, Carneiro ACO, Carvalho AMML, Cardoso MT, Hein PRG (2016). Effects of plant spacing on the physical, chemical and energy properties of Eucalyptus wood and bark. Journal of Tropical Forest Science 28 (3): 243248. [online] URL: http://www.jstor.org/stable/ 43856526

Santos RC, Carneiro ACO, Vital BR, Castro RVO, Vidaurre GB, Trugilho PF, Castro AFNM (2016). Influência das propriedades químicas e da relação siringil/guaiacil da madeira de eucalipto na produção de carvão vegetal [Effect of chemical properties and syringyl/guaiacyl ratio of wood clones of Eucalyptus on the production of charcoal]. Ciência Florestal 26 (2): 657-669. [in Portuguese] - doi: 10.5902/1980509822765

Silva JC, Tomazello Filho M, Oliveira JTS, Castro VR (2007). Influência da idade e da posição radial nas dimensões das fibras e dos vasos da madeira de $E$. grandis Hill ex. Maiden [Influence of age and radial position on fiber and vessel dimensions of E. grandis Hill ex. Maiden wood]. Revista Árvore 31 (6): 1081-1090. [in Portuguese] - doi: 10.1590/S0100-676220070006000 13

Souza CO, Silva JGM, Arantes MDC, Vidaurre GB, Dias Júnior AF, Oliveira MP (2020). Pyrolysis of Anadenanthera peregrina wood grown in different spacings from a forest plantation in Brazil aiming at the energy production. Environment, Development and Sustainability 22: 5153-5168. doi: 10.1007/s10668-019-00418-0

TAPPI (2006). T280 pm-99 standard: acetone extractives of wood and pulp. Technical Association of the Pulp and Paper Industry, Atlanta, USA, pp. 1-3.

Teixeira EC, Lima APL, Lima SF, Soratto DN, Ramos KV, Silva WG (2020). Potencial energético da madeira de clones de eucalipto em diferentes espaçamentos [Energetic potential of eucalyptus clones wood at different planting spacings]. Research, Society and Development 9 (7): e02973733. [in Portuguese] - doi: 10.3344 8/rsd-v9i7.3733

Torres CMME, Oliveira AC, Pereira BLC, Jacovine LAG, Neto SNO, Carneiro ACO, Torres CMME (2016). Estimativas da produção e propriedades da madeira de eucalipto em sistemas agroflorestais [Estimates of production and properties of eucalyptus wood in agroforestry systems]. Scientia Forestalis 44 (109): 137-148. [in Portuguese] - doi: 10.18671/scifor.v44n109.13

Watson P, Garner C, Robertson R, Reath S, Gee W, Hunt K (2003). The effects of initial tree spacing on the fibre properties of plantationgrown coastal western hemlock. Canadian Journal of Forest Research 33 (12): 2460-2468. doi: $10.1139 / \times 03-171$ 